\title{
ANALISIS NILAI KARAKTER PADA BUKU SISWA TEMATIK KELAS IV TEMA INDAHNYA KERAGAMAN DI NEGERIKU SUBTEMA INDAHNYA PERSATUAN DAN KESATUAN NEGERIKU
}

\section{Muhlis, Sukriadi, Felya Oktaviyanti, Kusdar, Iksam}

Fakultas Keguruan Dan Ilmu Pendidikan, Universitas Mulawarman, Samarinda, Indonesia

Email: muhclisart17@gmail.com, felyaoktvynti@gmail.com, sukriadi@fkip.unmul.ac.id, kusdar.kusdar@yahoo.com,iksam.iksam@yahoo.com

\begin{abstract}
Abstrak
Penelitian ini dilatarbelakangi oleh pentingnya penanaman nilai karakter kepada siswa, salah satunya melalui buku siswa. Penguatan Pendidikan Karakter (PPK) memiliki 5 nilai karakter yang terdiri dari Religius, Nasionalisme, Mandiri, Gotong Royong, dan Integritas. Jenis penelitian ini menggunakan pendekatan kualitatif, dengan jenis penelitian analisis deskriptif. Data yang diambil dalam penelitian ini adalah teks bacaan yang mengandung nilai karakter sesuai dengan PPK. Hasil penelitian menunjukkan bahwa, pada buku siswa tematik Tema Indahnya Keragaman di Negeriku Subtema Indahnya Persatuan dan Kesatuan Negeriku, semua nilai karakter utama PPK ditemukan sebanyak 41 nilai karakter. Nilai tersebut antara lain, nilai religius sebanyak 10 karakter, nilai nasionalisme sebanyak 20 karakter, nilai mandiri sebanyak 2 karakter, gotong royong sebanyak 2 karakter, dan nilai integritas sebanyak 7 karakter. Pada buku siswa tersebut nilai karakter yang paling mendominasi yaitu nilai nasionalisme. Keberadaan nilai karakter dalam teks bacaan buku siswa tidak merata dan tidak seimbang, terlihat dari adanya karakter yang lebih dominan dan lebih sedikit serta masih terdapat beberapa indikator dari nilai karakter yang belum terpenuhi. Berdasarkan hasil penelitian dapat disimpulkan bahwa semua nilai karakter utama PPK ditemukan sebanyak 41 nilai karakter pada teks bacaan dalam buku siswa tematik.
\end{abstract}

Kata Kunci: Analisis, Nilai Karakter, Buku Tematik, Tema Indahnya Persatuan dan Kesatuan Negeriku, Kurikulum 2013

This research is motivated by the importance of implementing character values in students, one of which is through student books. Strengthening Character Education (PPK) has 5 character values consisting of Religion, Nationalism, Independent, Mutual Cooperation, and Integrity. This research uses a qualitative approach, with the type of research descriptive analysis. The data taken in this study are reading texts containing character values according to the PPK. The results showed that, in the thematic student book Indahnya Keragaman di Negeriku Subtema Indahnya Persatuan dan Kesatuan Negeriku, 
all the main character values of KDP were found to be 41 character values. These values include 10 characters of religious value, 20 characters of nationalism value, 2 characters of independent value, 2 characters of mutual cooperation, and 7 characters of integrity value. In the student book, the most dominating character value is the value of nationalism. The existence of character values in student reading texts is uneven and unbalanced, as can be seen from the presence of more dominant and fewer characters and there are still several indicators of character values that have not been met. Based on the results of the study, it can be concluded that all the main character values of $P P K$ were found as many as 41 character values in reading texts in thematic student books.

Keywords: Analysis, Character Values, Thematic Books, The Beautiful Theme of Unity and Unity of My Country, 2013 Curriculum

Received: 2021-10-20; Accepted: 2021-11-05; Published: 2021-11-20

\section{Pendahuluan}

Undang-Undang Republik Indonesia Nomor 20 Tahun 2003 pasal 1 pendidikan adalah usaha sadar dan terencana untuk mewujudkan suasana belajar dan proses pembelajaran agar peserta didik secara aktif mengembangkan potensi dirinya untuk memiliki kekuatan spiritual keagamaan, pengendalian, kecerdasan, akhlak mulia, serta keterampilan yang diperlukan dirinya, masyarakat, bangsa dan negara. Karakter mengacu kepada serangkaian sikap (attitude), perilaku (behavior), motivasi (motivation), dan keterampilan (skill) (Nomor, 2003). Peraturan Menteri Pendidikan dan Kebudayaan Republik Indonesia Nomor 20 Tahun 2018 tentang Penguatan Pendidikan Karakter pada satuan Pendidikan Formal yaitu terdapat pada pasal 2 tentang Penguatan Pendidikan Karakter (PPK) (Pendidikan \& Nomor, 20AD). PPK dilaksanakan dengan menerapkan nilai-nilai Pancasila yang berkaitan dengan perwujudan dari 5 nilai utama yang saling berkaitan yaitu religius, nasionalis, mandiri, gotong royong, dan integritas yang terintegrasi dalam kurikulum.

Pendidikan karakter merupakan suatu penanaman nilai-nilai karakter kepada siswa dalam dunia pendidikan, karena pendidikan dijadikan sebuah tempat untuk membentuk pribadi anak agar bisa menjadi lebih baik. Pendidikan karakter bertujuan agar peserta didik sebagai penerus bangsa mempunyai akhlak dan moral yang baik, untuk menciptakan kehidupan berbangsaan yang adil, aman dan makmur.

Adi (2010: 63) menyatakan bahwa karakter sering sekali diartikan sebagai moral atau kepribadian yang dimiliki manusia. Buku ajar adalah buku yang dipergunakan sebagai buku pelajaran dalam bidang studi tertentu, yang merupakan buku standar yang telah disusun oleh pakar dalam bidangnya untuk maksud dan tujuan instruksional, yang dilengkapi dengan sarana pengajaran yang serasi dan lebih mudah dipahami oleh para pemakainya di sekolah dan perguruan tinggi sehingga dapat menunjang suatu programprogram pengajaran. Basuki (2015) menyatakan bahwa buku ajar tersusun atas beberapa komponen tertentu yaitu judul, materi pokok, latihan, informasi pendukung serta 
penilaian. Buku ajar bisa juga dijadikan sebagai alat dalam mencapai suatu tujuan yang dapat direncanakan didalam sebuah proses belajar dan mengajar.

Trianto (2012: 112) mendefinisikan bahwa buku siswa merupakan buku panduan bagi siswa dalam kegiatan pembelajaran yang memuat materi pelajaran, kegiatan penyelidikan berdasarkan konsep, kegiatan sains, informasi, dan contoh-contoh penerapan sains dalam kehidupan sehari-hari. Ayuningtyas dan Budiyono (2016: 23) mendefinisikan bahwa komponen materi atau isi yang ada pada buku siswa meliputi yaitu kesesuaian tujuan buku, serta kelengkapan yang terdapat dalam isi buku dari segi ketersediaan soal evaluasi maupun kesesuaian dengan kompetensi dasar yang ditentukan dari hasil penelitian dapat menunjukkan kualitas dengan kategori baik serta mudah untuk dimengerti oleh guru maupun siswa.

Analisis Nilai Karakter pada Buku Siswa Tematik Kelas IV Tema Indahnya Keragaman di Negeriku Subtema Indahnya Persatuan dan Kesatuan Negeriku dilakukan karena merupakan tema yang tepat dan cocok bagi siswa, dan sudah mewakili secara umum dari berbagai keragaman, sehingga perlu adanya analisis yang diajarkan kepada siswa, dan juga untuk membudayakan cinta keragaman terhadap negeri. Selain itu, karakter yang termuat didalamnya ada berbagai macam yang dapat meningkatkan pengetahuan siswa bahwa Indonesia memiliki banyak keanekaragaman yang harus kita jaga dan lestarikan.

Berdasarkan landasan di atas isi yang terdapat pada buku siswa dapat berpengaruh terhadap nilai-nilai karakter peserta didik, sehingga untuk mengetahui hal tersebut peneliti akan melakukan penelitian dengan rumusan masalah "Bagaimana nilai karakter yang terdapat pada buku siswa tematik kelas IV tema Indahnya Keragaman di Negeriku Subtema Indahnya Persatuan dan Kesatuan Negeriku?"

\section{Metode Peneletian}

\section{Jenis Penelitian}

Pada penelitian ini menggunakan penelitian analisis deskriptif. Masyhud (2014) menyatakan bahwa penelitian deskriptif merupakan suatu penelitian yang berusaha mendeskripsikan suatu keadaan, suatu kondisi secara ilmiah. Mendeskripsikan di sini dimaksudkan agar diperoleh gambaran yang jelas, objektif, dari suatu keadaan sebagaimana adanya, tanpa menghubungkan dengan keadaan atau suatu kondisi atau variabel lainnya.

Suryabrata (dalam Masyhud, 2014), tujuan dilaksanakan penelitian deskriptif adalah untuk membuat pencandraan secara sistematis, faktual, dan akurat mengenai fakta-fakta dan sifat-sifat populasi atau daerah tertentu. Dalam penelitian deskriptif ini, hanya dideskripsikan kondisi yang diamati semata-mata, tidak perlu mencari atau menerangkan saling hubungan, menguji hipotesis, membuat ramalan/prediksi, atau mendapatkan implikasi dari hasil penelitian yang dilakukan, meskipun penelitian tersebut bertujuan untuk menemukan suatu hal yang mencakup metode deskriptif. 


\section{Teknik Pengumpulan Data}

Teknik pengumpulan data digunakan untuk memperoleh informasi yang relevan dan akurat sesuai tujuan penelitian ini selain analisis yaitu teknik observasi, metode dokumentasi, dan memberi kode-kode nilai karakter PPK (Moenlihabib, 2003). Usman dan Akbar (2008), menyatakan teknik observasi merupakan pengamatan dan pencatatan yang sistematis terhadap fakta yang diteliti. Dalam menggunakan teknik observasi yang terpenting dalam penelitian ini yaitu mengandalkan pengamatan dan ingatan peneliti. Dokumentasi berasal dari kata dokumen yang berarti catatan peristiwa yang sudah berlalu (Sugiyono, 2013). Data dokumentasi pada penelitian ini yang digunakan adalah data yang terdapat pada buku siswa yang berupa nilai karakter pada buku siswa tematik kelas IV tema Indahnya Keragaman di Negeriku Subtema Indahnya Persatuan dan Kesatuan Negeriku edisi revisi 2016.

\section{Teknik Analilis Data}

Analisis data merupakan suatu proses mencari dan menyusun secara sistematis di mana data yang diperoleh dari catatan lapangan dan dokumentasi dengan cara mengorganisasikan data ke dalam kategori, menjabarkan ke dalam unit-unit tertentu, melakukan suatu sintesa, menyusun ke dalam pola, memilih mana yang penting dan akan dipelajari, dan membuat suatu kesimpulan sehingga mudah dipahami oleh semua orang baik orang lain maupun diri sendiri (Sugiyono, 2013). Teknis analisis data dilakukan dengan tujuan untuk mengorganisasi data, sehingga dapat memecahkan masalah dalam penelitian. Miles dan Huberman (dalam Sugiyono, 2013), analisis data kualitatif terdiri atas tiga tahap, yaitu tahap reduksi data, penyajian data, dan penarikan kesimpulan.

\section{Pembahasan}

Providing information without providing criticism related to violent events that occur within the school environment. Giving a response that this incident is something that should not have happened at school and of course has other negative impacts that may arise in the future will have an influence on readers that this is not appropriate and a good thing to do. This is necessary in the context of prevention which may indirectly affect the reader's subconscious.

Data yang ditemukan dalam penelitian ini adalah berupa teks bacaan. Dalam mengidentifikasi muatan nilai karakter peneliti bekerja dengan menelaah, mencermati, membaca serta mendalami, kemudian mengidentifikasi terkait indikator dari kelima masing-masing nilai, yaitu Religius, Nasionalisme, Mandiri, Gotong Royong, dan Integritas. Langkah berikutnya adalah membaca halaman demi halaman teks bacaan yang terdapat pada buku siswa tematik kelas IV Tema Indahnya Keragaman di Negeriku Subtema Indahnya Persatuan dan Kesatuan Negeriku dengan memberikan kode-kode nilai karakter PPK pada lembar pengumpulan data. Hal ini dilakukan apabila ditemukan salah satu nilai dari lima karakter yang muncul dalam teks bacaan.

Teks bacaan yang diidentifikasi dalam penelitian ini berjumlah tujuh teks bacaan. Teks bacaan sebanyak tujuh yaitu "Supaya Tetap Rukun, Mari Lakukan Sikap Ini", 
"Ayo Bercerita", "Keragaman budaya", "Keragaman Ekonomi di Indonesia", "Arti Penting Memahami Keragaman dalam Masyarakat Indonesia", "Sikap Toleransi terhadap Keragaman", dan "Melaksanakan Sikap Toleransi". Teks bacaan yang ditemukan memiliki pesan pada setiap teks bacaan baik secara tersurat maupun tersirat. Pesan yang disampaikan ini dapat membantu proses perkembangan karakter pada siswa.

Berikut adalah hasil identifikasi muatan nilai karakter yang muncul dalam 7 teks bacaan pada buku siswa tematik kelas IV Tema Indahnya Keragaman di Negeriku Subtema Indahnya Persatuan dan Kesatuan Negeriku:

Tabel 1

Hasil Identifikasi Nilai Karakter dalam Teks Bacaan

\begin{tabular}{|c|c|c|c|c|c|c|}
\hline \multirow[b]{2}{*}{ Subtema } & \multirow[b]{2}{*}{ Teks Bacaan } & \multicolumn{5}{|c|}{ Nilai-Nilai Karakter } \\
\hline & & Religius & Nasionalisme & Mandiri & $\begin{array}{l}\text { Gotong } \\
\text { Royong }\end{array}$ & Integritas \\
\hline \multirow{8}{*}{$\begin{array}{l}\text { Subtema 3: } \\
\text { Indahnya } \\
\text { Persatuan } \\
\text { dan } \\
\text { Kesatuan } \\
\text { Negeriku }\end{array}$} & $\begin{array}{lr}\text { Supaya } & \text { Tetap } \\
\text { Rukun, } & \text { Mari } \\
\text { Lakukan } & \text { Sikap } \\
\text { Ini } & \\
\end{array}$ & 1 & 2 & 1 & - & 1 \\
\hline & Ayo Bercerita & - & 1 & - & - & - \\
\hline & $\begin{array}{l}\text { Keragaman } \\
\text { Budaya }\end{array}$ & - & 1 & - & - & - \\
\hline & $\begin{array}{l}\text { Keragaman } \\
\text { Ekonomi di } \\
\text { Indonesia }\end{array}$ & - & 3 & 1 & - & 2 \\
\hline & $\begin{array}{l}\text { Arti Penting } \\
\text { Memahami } \\
\text { Keragaman } \\
\text { dalam } \\
\text { Masyarakat } \\
\text { Indonesia }\end{array}$ & - & 2 & - & - & - \\
\hline & $\begin{array}{l}\text { Sikap Toleransi } \\
\text { Terhadap } \\
\text { Keragaman }\end{array}$ & 9 & 9 & - & - & 2 \\
\hline & $\begin{array}{l}\text { Melaksanakan } \\
\text { Sikap Toleransi }\end{array}$ & - & 2 & - & 2 & 2 \\
\hline & Jumlah & 10 & 20 & 2 & 2 & 7 \\
\hline
\end{tabular}

Sumber: Hasil Penelitian, Buku Siswa Tematik, 2021

Berdasarkan tabel hasil identifikasi muatan nilai karakter tersebut ditemukan sejumlah 41 muatan nilai karakter yang terdiri dari nilai religius, nasionalisme, mandiri, gotong royong, dan integritas. Frekuensi kemunculan nilai karakter tersebut tidak merata dan tergantung dengan fokus pengembangan karakter dari buku siswa.

Adapun rincian jumlah setiap karakter yang sesuai dengan Penguatan Pendidikan Karakter (PPK), yaitu (a) nilai religius 10, ditunjukkan dengan adanya indikator yang sesuai dengan teks bacaan, yaitu menjaga kerukunan dan lingkungan hidup di sekitar 
rumah tempat tinggal sekolah dan masyarakat, memelihara hubungan baik sesama umat ciptaan Tuhan Yang Maha Esa, dan menghormati orang lain menjalankan ibadah sesuai dengan agamanya; (b) nilai nasionalisme 20, ditunjukkan dengan adanya indikator yang sesuai dengan teks bacaan, yaitu cinta tanah air, menjunjung cita-cita bangsa, melestarikan budaya, dan memelihara nilai-nilai leluhur; (c) nilai mandiri 2, ditunjukkan dengan adanya indikator yang sesuai dengan teks bacaan, yaitu memiliki kemampuan inisiatif, membuat pertimbangan sendiri dalam bertindak dan bertanggung jawab, percaya diri, berkeinginan sesuatu tanpa bantuan orang lain, dan puas terhadap hasil usaha sendiri. (d) nilai gotong royong 2, ditunjukkan dengan adanya indikator yang sesuai dengan teks bacaan, yaitu bersedia membantu orang lain tanpa mengharap imbalan dan tidak mendahulukan kepentingan pribadi. (e) nilai integritas 7, ditunjukkan dengan adanya indikator yang sesuai dengan teks bacaan, yaitu tidak berbohong, mengakui dan meminta maaf atas kesalahan yang dilakukan, dan menerima resiko dari tindakan yang dilakukan.

Berdasarkan data yang diperoleh dari hasil penelitian, bahwa secara keseluruhan nilai karakter utama PPK dalam buku siswa tematik tema Indahnya Keragaman di Negeriku Subtema Indahnya Persatuan dan Kesatuan Negeriku ditemukan sebanyak 41 nilai karakter. Nilai karakter yang mendominasi yaitu nilai nasionalisme. Karakter berkaitan dengan kebaikan sehingga hal-hal baik yang ditemukan dalam buku tematik siswa merupakan pembiasaan yang menanamkan nilai karakter pada peserta didik (Lickona, 2004). Pada buku siswa tematik, ditemukan nilai karakter utama PPK yang dikembangkan sesuai dengan perkembangan siswa kelas IV yang dijelaskan dalam Peraturan Menteri Pendidikan dan Kebudayaan (Permendikbud) Nomor 20 Tahun 2018.

Pertama, nilai religius mencerminkan keberimanan terhadap Tuhan yang Maha Esa. Terdapat beberapa nilai yang terkandung dalam nilai religious yaitu, toleransi, cinta damai, persahabatan, teguh pendirian, ketulusan, percaya diri, tidak memaksakan kehendak, mencintai lingkungan, kerja sama antar pemeluk agama dan kepercayaan, melindungi yang kecil dan tersisih. Didalam buku siswa tematik, ditemukan nilai religius yang menunjukkan tentang bersyukur atas nikmat dan karunia Tuhan Yang Maha Esa, berserah diri (tawakal) kepada Tuhan setelah berikhtiar atau melakukan usaha, menjaga lingkungan hidup di sekitar rumah tempat tinggal sekolah dan masyarakat, memelihara hubungan baik sesama umat ciptaan Tuhan Yang Maha Esa, dan menghormati orang lain menjalankan ibadah sesuai dengan agamanya. Kemudian ditemukan nilai religius melalui kegiatan dan sikap yang menunjukkan tentang melaksanakan ajaran agama sesuai yang dianutnya, melalui kegiatan berdoa sesuai waktu yang sudah ditentukan. Selain itu juga ada nilai toleransi antar teman yang berbeda, baik agama, suku, budaya, dan ras. Lalu sikap yang mencintai perdamaian, persahabatan, tidak memaksakan kehendak serta peduli dengan sesama dan lingkungan. Hal ini sejalan dengan pendapat Muchlis (2011 :84), tentang nilai karakter adalah nilainilai perilaku manusia yang berhubungan dengan Tuhan Yang Maha Esa, diri sendiri, sesama manusia, lingkungan dan kebangsaan. Oleh sebab itu, nilai karakter religius bukan hanya berkaitan tentang hubungan kita dengan Tuhan, namun juga bagaimana 
sikap dan perilaku kita dengan lingkungan yang ada di sekeliling kita yang seringkali diabaikan.

Kedua, nilai nasionalisme yaitu menempatkan kepentingan bangsa dan negara di atas kepentingan diri dan kelompoknya. Terdapat beberapa nilai yang terkandung dalam nilai nasionalis diantaranya yaitu, taat hukum, disiplin, cinta tanah air, menghormati keragaman budaya, suku, bangsa dan agama, menjaga kekayaan budaya bangsa, rela berkorban, dan menjaga lingkungan. Didalam buku siswa tematik, ditemukan nilai nasionalisme yang menunjukkan tentang cinta tanah air, menjunjung cia-cita bangsa, melestarikan budaya, dan memelihara nilai-nilai leluhur. Kemudian ditemukan nilai nasionalisme ditunjukkan melalui sikap yang taat akan aturan yang berlaku, baik di sekolah dan juga di masyarakat. Contohnya dengan memelihara lingkungan sekitar dengan cara tidak membuang sampah sembarangan, menjaga dan melestarikan budaya, menghormati suku, agama, ras dan adat istiadat, sikap yang rela berkorban bagi bangsa dan negara, serta mencintai tanah air. Kemudian juga ikut serta dalam mempelajari dan menjaga budayanya agar tetap ada, karena seiring perkembangan zaman seringkali budaya tradisional mulai ditinggalkan oleh generasi sekarang. Dalam bagian ini belum ditemukan nilai nasionalisme yang berkaitan dengan kedisiplinan dan juga berprestasi, padahal bagian tersebut membantu siswa untuk terus menggali potensi dalam diri mereka. Hal ini sejalan dengan pendapat Sedyawati (2007), bahwa setiap daerah memiliki ciri khas dan istilah masing-masing dalam budayanya. Meskipun memiliki perbedaan istilah, namun arti yang diungkapkan sama. Berbagai bentuk budaya daerah merupakan akar dari budaya nasional, jika budaya daerah berkembang maka budaya nasional juga turut berkembang kemudian keberagaman tersebut mampu memperkokoh persatuan dan kesatuan bangsa.

Ketiga, nilai mandiri yaitu sikap dan perilaku yang tidak bergantung pada orang lain dan mempergunakan tenaga, pikiran, waktu untuk merealisasikan harapan, mimpi dan cita-cita. Mandiri bagi anak sangat penting dengan mempunyai sifat mandiri, anak tidak akan mudah bergantung kepada orang lain. Terdapat beberapa nilai yang terkandung dalam nilai mandiri diantaranya yaitu, kerja keras, tangguh tahan banting, daya juang, profesional, kreatif dan keberanian. Didalam buku siswa tematik, ditemukan nilai mandiri yang menunjukkan tentang menemukan identitas diri, memiliki kemampuan inisiatif, membuat pertimbangan sendiri dalam bertindak dan bertanggung jawab atas tindakannya, dapat mengambil keputusan sendiri dalam kemampuan memilih, percaya diri, berkeinginan sesuatu tanpa bantuan orang lain. Kemudian ditemukan nilai mandiri ditunjukkan melalui sikap yang tidak mudah bergantung dengan orang lain, kreatif, berani, profesional dalam mengerjakan sesuatu serta bekerja keras. Contohnya dengan kegiatan yang dilakukan disekolah dan dirumah seperti mengerjakan tugas sekolah sendiri dan merapikan barang-barang sendiri. Hal ini sejalan dengan pendapat Chaplin (2011 :343) bahwa kemandirian merupakan kondisi dimana seseorang tidak tergantung pada orang lain dalam menemukan keputusan dan adanya sikap percaya diri. Kemudian dari hal-hal tersebut, siswa dapat belajar untuk tidak mudah menyerah dalam mengerjakan sesuatu, terus mencoba hingga berhasil. 
Keempat, nilai gotong royong, mencerminkan tindakan menghargai semangat kerja sama dan bahu membahu menyelesaikan persoalan bersama. Terdapat beberapa nilai yang terkandung dalam nilai gotong royong diantaranya yaitu, menghargai sesama, kerja sama, solidaritas, empati, tolong menolong, anti diskriminasi, anti kekerasan, memiliki sikap kerelawanan dan komitmen atas keputusan bersama. Didalam buku siswa tematik, ditemukan nilai gotong royong yang menunjukkan tentang bersedia membantu orang lain tanpa mengharap imbalan, tidak mendahulukan kepentingan pribadi, dan mencari jalan untuk mengatasi perbedaan pendapat atau pikiran anatara diri sendiri dan orang lain. Kemudian terdapat nilai gotong royong ditunjukkan melalui sikap dan tindakan yang saling tolong menolong dan bekerja sama, bermusyawarah untuk menentukan keputusan, berkomitmen atas keputusan bersama, anti kekerasan, anti deskriminasi serta memiliki rasa solidaritas. Melalui kegiatan mengerjakan tugas kelompok bersama dengan teman-teman, menghargai pendapat yang berbeda ketika diskusi di dalam kelas, melakukan musyawarah ketika mengambil keputusan bersama misalnya pemilihan pengurus kelas dan saling membantu ketika mendapat jadwal membersihkan kelas. Hal ini sejalan dengan pendapat Sudrajat (2014: 14) bahwa gotong royong adalah bentuk solidaritas sosial, terbentuk karena adanya bantuan dari pihak lain, untuk kepentingan pribadi maupun kelompok sehingga di dalamnya terdapat sikap loyal dari setiap warga sebagai satu kesatuan. Setiap hal tersebut merupakan bagian yang diperlukan siswa, untuk mempersiapkan diri ketika masuk ke dalam lingkungan yang lebih luas. Karena manusia merupakan makhluk sosial, sehingga memerlukan orang lain di sekitarnya.

Kelima, nilai integritas, merupakan nilai yang mendasari perilaku yang didasarkan pada upaya menjadikan dirinya sebagai orang yang selalu dapat dipercaya dalam perkataan, tindakan, dan pekerjaan, memiliki komitmen dan kesetiaan pada nilai-nilai kemanusiaan dan moral. Nilai integritas dapat ditunjukkan dengan sikap tanggung jawab, peduli sosial, kesetiaan, berkata dan berperilaku berdasarkan kebenaran, menghargai sesama, mampu menunjukkan keteladanan. Didalam buku siswa tematik, ditemukan nilai integritas yang menunjukkan tentang mengakui dan meminta maaf atas kesalahan yang dilakukan dan menerima resiko dari tindakan yang dilakukan. Kemudian terdapat nilai integritas ditunjukkan melalui sikap yang menunjukkan keteladanan dan tanggung jawab dalam mengerjakan tugas dengan baik, memiliki komitmen dan kesetiaan pada nilai-nilai kemanusian dan moral, menghargai sesama, serta peduli dengan lingkungan sosial. Melalui nilai tersebut memberikan pemahaman tentang sikap yang bertanggungjawab, misalnya ketika mengerjakan tugas dikerjakan dengan sungguh-sungguh, dikerjakan dengan jujur dan dipersiapkan dengan baik. Hal ini sejalan dengan pendapat Harisa (2011: 2-8) bahwa integritas sebagai identitas praktis yang merupakan komitmen mendasar dalam mencari makna dan tujuan hidup, orang yang memiliki integritas akan senantiasa mempertahankan komitmen dalam dirinya meskipun banyak pertentangan atau situasi yang memaksa mereka untuk melanggar komitmennya sendiri. Hal ini merupakan salah satu bagian yang penting, karena bukan hanya tentang siswa yang dapat mengerjakan tugas dengan baik saja, namun juga sangat 
penting bahwa siswa mengerjakan tugas yang diberikan dengan jujur dan tidak menyontek dengan temannya.

Berdasarkan deskripsi hasil analisis tentang nilai karakter utama PPK, yang terdapat dalam buku siswa tematik telah ditemukan nilai karakter dalam setiap pembelajaran. Namun, dengan jumlah kemunculan yang berbeda-beda. Pada buku siswa tematik kelas IV tema Indahnya Keragaman di Negeriku Subtema Indahnya Persatuan dan Kesatuan Negeriku ini, nilai karakter yang paling banyak mendominasi yaitu nilai nasionalisme sebanyak 20 karakter. Kemudian nilai yang paling sedikit ditemukan yaitu, nilai mandiri dan gotong royong sebanyak 2 karakter. Melihat dari data tersebut, bahwa setiap nilai karakter itu sangatlah berperan penting dalam membentuk karakter siswa. Namun, perlu ditingkatkan dan dikembangkan lagi dalam bagian ini adalah nilai karakter mandiri dan gotong royong, karena seseorang bisa bentuk solidaritas sosial dan kemandirian, terbentuk karena adanya bantuan dari pihak lain, untuk kepentingan pribadi maupun kelompok sehingga di dalamnya terdapat sikap loyal dari setiap warga sebagai satu kesatuan. Setiap hal tersebut merupakan bagian yang diperlukan siswa, untuk mempersiapkan diri ketika masuk ke dalam lingkungan yang lebih luas. Karena manusia merupakan makhluk sosial, sehingga memerlukan orang lain di sekitarnya. Oleh sebab itu, setiap nilai karakter tersebut harus terus ditanamkan sejak dini kepada siswa yang akan menjadi generasi penerus bangsa. Kegiatan yang ditemukan dalam rancangan dan proses pembelajaran pada buku siswa ini, sudah berkaitan dengan nilai karakter dan terus memberikan latihan kepada peserta didik untuk berpikir dan bertindak dengan terarah pada nilai karakter.

\section{Kesimpulan}

Berdasarkan hasil analisis nilai karakter pada buku siswa tematik kelas IV tema Indahnya Keragaman di Negeriku subtema Indahnya Persatuan dan Kesatuan Negeriku terdapat lima nilai karakter yang sesuai dengan Penguatan Pendidikan Karakter (PPK) kelima nilai karakter tersebut adalah nilai religius, nilai nasionalisme, nilai mandiri, nilai gotong royong, dan nilai integritas. Berikut adalah rincian jumlah nilai karakter yang sesuai dengan yang terdapat pada buku siswa yaitu:

1. Religius 10 nilai karakter

2. Nasionalisme 20 nilai karakter

3. Mandiri 2 nilai karakter

4. Gotong-royong 2 nilai karakter

5. Integritas 7 nilai karakter

Pada buku siswa tersebut nilai karakter yang paling mendominasi yaitu nilai nasionalisme. Kemudian disusul dengan urutan berikutnya adalah nilai religius, integritas, mandiri, dan gotong royong. Keberadaan nilai karakter dalam teks bacaan buku siswa tidak merata dan tidak seimbang, terlihat dari adanya karakter yang lebih dominan dan lebih sedikit serta masih terdapat beberapa indikator dari nilai karakter yang belum terpenuhi. 
Nilai karakter yang tercantum pada tema Indahnya Keragaman di Negeriku subtema Indahnya Persatuan dan Kesatuan Negeriku yang sebagian besar indikatornya telah sesuai dengan silabus. Hasil penelitian ini diperoleh dari teks bacaan yang terdapat pada buku siswa tematik kelas IV tema Indahnya Keragaman di Negeriku subtema Indahnya Persatuan dan Kesatuan Negeriku, yang nantinya akan digunakan untuk diajarkan sebagai nilai moralitas dalam berbahasa dan bernegara pada anak sekolah dasar. 


\section{BIBLIOGRAPHY}

Lickona, Thomas. (2004). Character matters: How to help our children develop good judgment, integrity, and other essential virtues. Simon and Schuster. Google Scholar

Masyhud, Sulthon. (2014). Metode penelitian pendidikan. Jember: Lpmpk, 80. Google Scholar

Moenlihabib, M. (2003). Dasar- Dasar Metodologi Penelitian. Google Scholar

Nomor, Undang Undang Republik Indonesia. (2003). Tahun 2003 Sistem Pendidikan Nasional. 8 Juli 2003. Lembaran Negara Republik Indonesia Tahun. Google Scholar

Pendidikan, Peraturan Menteri, \& Nomor, Kebudayaan Republik Indonesia. (20AD). Tahun 2018 tentang Penguatan Pendidikan Karakter pada Satuan Pendidikan Formal. Jakarta: Kemendikbud. Google Scholar

Sugiyono, Dr. (2013). Metode penelitian pendidikan pendekatan kuantitatif, kualitatif dan $R \& D$. Google Scholar

Usman, Husaini, \& Akbar, Purnomo Setiady. (2008). Metodologi penelitian sosial. Bumi Aksara. Google Scholar

\section{Copyright holder:}

Muhlis, Sukriadi, Felya Oktaviyanti, Kusdar, Iksam (2021)

First publication right:

Syntax Literate: Jurnal Ilmiah Indonesia

This article is licensed under:

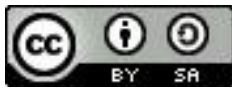

